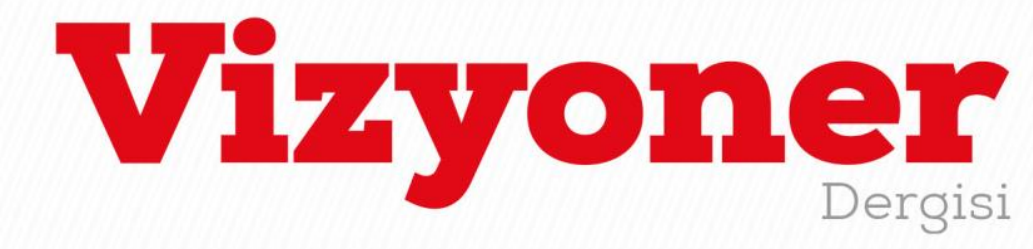

Süleyman Demirel Üniversitesi Vizyoner Dergisi, Yıl: 2020, Cilt: 11, Sayı: Ek, 50-64.

Süleyman Demirel University Visionary Journal, Year: 2020, Volume: 11, No: Supplement, 50-64.

\title{
DIŞLANMA VE TÜKENMISSLLIK SARMALINDA ÖRGÜT TEMELLİ ÖZ SAYGI: HİZMET SEKTÖRÜNDE BİR ARAŞTIRMA*
}

\section{ORGANIZATION-BASED SELF-ESTEEM IN THE SPIRAL OF OSTRACISM AND BURNOUT: A RESEARCH IN THE SERVICE SECTOR}

\author{
Dr. Öğr. Üyesi Mehmet Ali TÜRKMENOĞLU ${ }^{1}$
}

\section{ÖZ}

Örgütleri ve bireyleri etkileyen etmenlerden olan dışlanma ve tükenmişlik araştırmacıların ve profesyonellerin zihinlerini meşgul eden olumsuz davranış olarak görülmektedir. Son yıllarda araştırmacılar ve düşünürler bu tür sorunlu davranışların nedenlerini, sonuçlarını ve bunlara etki eden değişkenleri saptamaya çalışmaktadırlar. $\mathrm{Bu}$ araştırma ise iş yerinde dışlanmanın bireylerin tükenmişlik düzeylerine etkisini ve bu etkide örgüt temelli öz saygının aracılık rolünün incelemesini amaçlamaktadır. Şanlıurfa ilinde 401 hizmet sektörü çalışanıyla yapılan bu araştırma için nicel araştırma yöntemi benimsenmiş̧tir. Yapısal eşitlik modellemesi ile yapılan analizler sonucu, iş yerinde dışlanmanın tükenmişlik üzerinde pozitif bir etkiye sahip olduğu ve iş yerinde dışlanmanın örgüt temelli öz saygı üzerinde negatif yönlü etkisi olduğu saptanmıştır. Örgüt temelli öz saygının tükenmişlik üzerinde negatif bir etkiye sahip olduğu görülürken, örgüt temelli öz saygının işyerindeki dışlanma ve tükenmişlik arasındaki ilişkiye aracılık ettiği ortaya konmuştur. Araştırmanın sonuçlarına göre örgütlerde kapsayıcı bir kültür oluşturulması, etik kurallar belirlenip işletilmesi ve örgütsel adalet algısının iyileştirilmesi önerilmiştir. Araştırmanın sınırlılıkları ve gelecek çalışmalara yön gösterebilecek bazı kavramlar ifade edilmiştir.

Anahtar Kelimeler: İş Yerinde Dışlanma, Tükenmişlik, Örgüt Temelli Öz Saygı, Yapısal Eşitlik Modellemesi (YEM), Hizmet Sektörü.

JEL Sinıflandırma Kodları: M12, D23, C12.

\begin{abstract}
Ostracism and burnout that affect organizations and individuals are detrimental behaviors which have been preoccupying the minds of researchers and professionals. In recent years, scholars and researchers have been trying to understand the causes and effects of these troubling behaviors. The study aims to examine the effects of workplace ostracism on burnout and the mediator role of organization-based self-esteem in this effect. A quantitative method is employed to conduct this research with 401 service sector employees in the province of Şanlıurfa. Based on the data analysis with structural equation modelling (SEM), it emerged that workplace ostracism has a positive effect on burnout, and workplace ostracism has a negative effect on organization-based self-esteem. Moreover, while organization-based self-esteem has a negative effect on burnout, it is also shown that self-esteem mediates the relationship between workplace ostracism and burnout. According to the results of the study, forming an inclusive organizational culture, establishing and operating codes of ethics and improving organizational justice are recommended. The limitations of the study and future research are explained.
\end{abstract}

\footnotetext{
Bu çalışma için, Muş Alparslan Üniversitesi Etik Kurulundan 10879717-050.01.04 sayılı ve 24.06.2020 tarihli "Etik Kurul Onayı" alınmıştır.

(D) Muş Alparslan Üniversitesi, İktisadi ve İdari Bilimler Fakültesi, İşletme Bölümü, dr.mturkmenoglu@gmail.com

Makale Geliş Tarihi / Received : : 30.06.2020

Makale Kabul Tarihi / Accepted $\quad: 12.11 .2020$ 
Süleyman Demirel Üniversitesi Vizyoner Dergisi, Yıl: 2020, Cilt: 11, Sayı: Ek, 50-64.

Süleyman Demirel University Visionary Journal, Year: 2020, Volume: 11, No: Supplement, 50-64.

Keywords: Workplace Ostracism, Burnout, Organization-Based Self-Esteem, Structural Equation Modelling (SEM), Service Sector.

JEL Classification Codes: M12, D23, C12.

\section{GİRIŞ}

Son yıllarda sıkça sözü edilen tükenmişlik sendromu hem araştırmacıların hem de toplumun merak ettiği bir konudur. Bireylerin tükenmişlik halleri sadece örgütleri ve bireyleri olumsuz etkilemeyip, aynı zamanda örgütsel verimliliğe ve bireysel sağlığa tehdit teşkil etmektedir. Son birkaç yılda bu kavramı inceleyen çalışmaların artış hızına bakıldığında, düşünürler ve araştırmacılar bu sorunun neden kaynaklandığını ve nelerin tükenmişliği azaltabileceğine kafa yorduklarını göstermektedir. İlk olarak alanyazında tükenmişlik tanısı 1974 yılında sağlık hizmeti veren doktorlarda bitkinlik, motivasyon kaybı, odaklanamama gibi semptomlar ortaya çıkınca kullanılmıştır (Freudenberger, 1974). Tükenmişlik, baskı ve stresin gittikçe arttı̆̆ durumlarda, bireylerin artık bitkin ve yetersiz hissettikleri ve kronik yorgunluğun aniden öfkelenme ile kendini gösteren bir bitkinlik halidir (Maslach, 1982). Sosyal hayatta olduğu gibi iş hayatında da özellikle insanlarla çokça etkileşim içerisinde olunan kişilerde, örneğin sağlık ve eğitim sektörü çalışanlarında daha çok ortaya çıkan bu hal araştırmacıların üzerine kafa yordukları bir konu olmuştur. Sağlık ve eğitim gibi hizmet sektöründe yapılan araştırmalara göre örgütsel ve bireysel birçok faktör çalışanların tükenmelerine neden olmaktadır. Örneğin örgütsel adalet algılarının zayıflaması sonucu otel çalışanlarının tükendikleri saptanmıştır (Pelit ve Bozdoğan, 2014). Benzer şekilde iş yükü, stres, psikolojik yıldırma gibi nedenlerle de çalışanlar tükenmişlik düzeyleri artmaktadır (Sart, Sezgin ve Demir, 2018; Faiz, 2019) fakat bu değişkenler arasında iş yerinde dişlanmanın tükenmişliğe bir öncül olup olamayacağı pek fazla tartışılmamıştır. Dolayısıyla, bu çalışma bahsi geçen boşluğu doldurmak için iş yerinde dışlanmanın tükenmişlik üzerinde bir etkisinin olup olmadığını araştırmaya çalışacaktır.

İşyerinde dışlanma insanın aidiyet gereksiniminin karşılanmasının önünde ciddi bir engel olup üzücü bir durumdur. Dışlanma, bireyin fiziksel veya sosyal olarak yok sayıldığı, reddedildiği, kararlara davet edilmediği, aynı ortamda istenmediği durumlarda ortaya çıkan bir durumdur. Yürütülen araştırmalara göre dışlanan bireylerin işe yabancılaştığı, örgütsel sinizm geliştirdikleri ve işten ayrılma niyetlerini artırdığı görülmektedir (Abaslı, 2018; Soybalı ve Pelit, 2018; Yıldırım ve Akın, 2018). Bu araştırmada ise yukarıda bahsedilen olumsuz davranışlar kategorisine girebilecek olan işyerinde dışlanma ile tükenmişlik arasındaki ilişki ve bu ilişkide örgüt temelli öz saygının rolü (ÖTÖS) incelenmeye çalışılacaktır. Bu araştırmanın savına göre iş yerinde dışlanma bireylerin tükenmişlik düzeylerine etki eder fakat bireyler örgüt temelli öz saygılarından ötürü tükenmezler. Yapılan araştırmalara göre öz saygısı yüksek olan bireyler kendilerini değerli ve önemli olarak görüp ve örgütlerine faydalı olduklarını düşündükleri için bedenen ve ruhen tükenmeyecekleri beklenmektedir (Lee ve Pecci, 2007; Uçar ve Ötken, 2010). Dolayısıyla bu araştırma dışlanan çalışanların tükeneceklerini beklemektedir ve tükenecekleri düşünülen bireyler de iş yerinde sorunlar yaşayabilirler. Bu sorunları yaşamamak için, bir başka ifadeyle, bireyler dışlansa bile öz saygıları sayesinde tükenmeyeceklerdir; çünkü öz saygıları güçlü olan bireylerin tükenme seviyeleri düşük olacaktır. Bu açıdan çalışma öz saygıyı dışlanan bireylerin tükenmemesi için araştırılmaya değer bir değişken görmektedir.

Bu araştırma iş yerinde dışlanma, tükenmişlik ve örgüt temelli öz saygının bir arada bulunduğu ilk araştırma olması ile özgün olup, literatürdeki bu anlamlı bir boşluğu ampirik bir araştırma ile doldurmayı hedeflemektedir. Makalenin yapısı kısaca şöyledir: girişle başlayan bölümde araştırmanın önemine değinilip ilgili kavramlardan bahsedilmiştir. Kuramsal çerçeve bölümünde dışlanma, tükenmişlik ve öz saygı açıklanmıştır, bu değişkenler arasındaki ilişkileri ortaya konup ve sırasıyla hipotezler oluşturulmuştur. Sonraki bölümde çalışmanın yöntemi açıklanıp, tartışmaya geçilmiştir. En son bölümde ise çalışmanın sonucu anlatılıp, araştırmanın katkılarından ve sınırlılıklarından bahsedilmiştir.

\section{KURAMSAL ÇERÇEVE VE HIPOTEZLERİ OLUŞTURMA}

\subsection{Dışlanma ve İşyerinde Dışlanma}

İş yerinde dışlanma, İngilizce Ostracism kavramının iş yerindeki bağlamına dayanır. İlk defa 1960'lı yıllarda Avrupa'da gündeme gelen dışlanma kavramı, Fransa'da yoksulların sadece yoksullukları sebebiyle değil aynı 
zamanda ekonominin sunduğu refahtan faydalanamadıklarından dolayı dışlandıkları savı üzerine kullanılmaya başlanmıştır (Sapancal1, 2005: 59). Bu kapsamda asosyal, engelli, marjinal, tek ebeveynli kişiler, göçmenler, kadınlar, suçlular ve madde bağımlıları dışlanmış kişiler olarak nitelendirilmiştir (Topateş, 2009: 122). Kavram, yoksulları ekonomik zenginliğe ulaşamaması üzerine kurulmasına rağmen, düşünürler dışlanmanın aslında bireylerin genel olarak topluma entegre olamaması sonucu gerçekleştiğini ifade ederler (Walker ve Walker, 1997: 8). Başka bir deyişle, dışlanma bireylerin sosyal, siyasal, kültürel, ekonomik unsurları kullanmayıp toplumla entegre olamaması halidir. Dışlanmayı ele alan bilim insanları ve düşünürler, dışlanmanın toplumun her alanında karşılaşılabilecek bir durum olduğunu, hatta bir takım hayvan deneylerinde bazı hayvanların dışlandığını saptamışlardır (Williams, 1997: 133). Buna göre dışlanma yalın anlamda dışarıda tutulma, yok sayılma, reddedilme anlamlarına gelmektedir. Dışlanma fiziksel olabileceği gibi sosyal olarak da meydana gelebilir, sözgelimi bir bireyin görmezden gelinmesi sosyal dışlanmaya, o bireyin aynı ortam dışında tutulması ise fiziksel dışlanmaya örnek verilebilir (Karabey, 2014: 3). Sosyal olarak dışlanan birey fiziksel olarak aynı ortamda olmasına rağmen, görmezden gelinerek, yok sayılarak dışlanmış sayılır.

Dışlanmanın alanyazındaki kavramsallaştırmaları incelendiğinde dışlanma derecelerine göre kategorize edilebilir. Örneğin, İngilizcede kullanılan Ostracism, yani bireyin görmezden gelinmesindeki dışlanmanın dozu düşüktür. Dışlanmanın şiddetinin arttı̆̆ı durumlarda ise bireyler önemli davetlere çağrılmaz ve dinlenmezler buna ise Exclusion yani bireyin sosyal dışlanması denir. Son olarak, çok daha şiddetli dışlanma durumlarına ise Rejection yani reddedilme denir, bu aşamada bireylerin bilerek dışlandığı açıkça belli edilir (Williams, 2007: 429). Bu çalışmada ise Workplace Ostracism şeklinde ifade edilen yani işyerinde dışlanma ve bunun tükenmişlik üzerine araştırılmaya çalışılmaktadır.

Çalışan bireyler, vakitlerinin önemli bir kısımlarını iş yerlerinde geçirdikleri ve sosyal ilişkiler geliştirdikleri düşünüldüğünde işyerleri çalışanlar için önemli bir sosyal mekandır. Buna göre işyeri, dışlanmanın gerçekleşebileceği en çok öne çıkan sosyal ortamlardan biri sayılabilir (Fox ve Stallworth, 2005: 438). Yürütülen araştırmalara göre, işyerinde bireylerin, diğer birey veya gruplar tarafından yok sayıldığı, görmezden gelindiği, ihmal edildiği, önemsenmediği, kararlara katılımlarının istenmediği, göz ardı edildiği, dışarıda tutulduğu tüm davranışlara işyerinde dişlanma denir (Ferris, Brown, Berry ve Lian, 2008; Leung, Wu, Chen ve Young, 2011; Robinson, O'Reilly ve Wang, 2013; Wu, Liu, Kwan ve Lee, 2016). Maslow'un ihtiyaçlar hiyerarşisine göre bireyler kendini gerçekleştirme yolunda belli bir gruba ait olma, saygı görme gibi gereksinimlere ihtiyacı vardır. Doğal olarak, birey belli bir sosyal gruba girmek isteyebilir fakat bu kurama göre dışlanan birinin bu ihtiyaçları giderilmediğinden ve sosyal olarak ayrımcılığa uğradığından dolayı üzgünlük, moral bozukluğu ve stres yaşamaları kaçınılmaz hale gelir. Bu üzücü ve ıstırap veren dışlanma bireyin hem psikolojisini negatif yönde etkilerken hem de iş ile ilgili davranışlarını etkiler (Hitlan, Cliffton ve DeSoto, 2006). Yapılan araştırmalar da bunu doğrular niteliktedir, örneğin Zhao, Peng ve Sheard (2013) yürüttükleri bir araştırmada işyerinde dışlanan bireylerin iş ile ilgili performanslarının düştüğünü ortaya koymuşlardır. Benzer şekilde, yakın zamanda gerçekleştirilen araştırmalara göre, dışlanan çalışanların stres seviyelerinin yükseldiği ve işten ayrılma niyetlerinin arttığı görülmektedir (Yin ve Liu, 2013; Vui Yee ve Yen Hwa, 2019). Bu çalışmada ise işyerinde dışlanmanın tükenmişliğe etkisinin ve bu ilişkide örgüt temelli öz saygının aracı rolü araştırılması amaçlanmaktadır.

\section{2. İş Yerinde Dışlanma ve Tükenmişlik Arasındaki İlişki}

İngilizcedeki ifadeyle Burnout olan tükenmişlik, özellikle hizmetin daha çok öne çıktığı alanlarda yaşanan olumsuz bir ruhsal durumdur (Maslach, Schaufeli ve Leiter, 2001). Tükenmişlik ilk defa 1974 y1lında kullanılmıştır. Freudenberger (1974), bu sorunu akıl sağlığı doktorlarının uzun süre gözlenmesinden sonra yakındıkları enerji kaybını ve motivasyonlarının düşmesi sonucu kullanmıştır. Bu durum, başta sağlık alanındaki olmak üzere eğitim-öğretim, sosyal hizmetler sunulan ve karşılıklı etkileşime dayalı işlerde çalışan kişilerde görülmektedir (Yürür, 2011: 108). Tükenmişlik, etkileşim içinde olunan tarafın aşırı taleplerine, kaynakları bakımında yetişilememesi sonucu uzun zaman içinde ortaya çıkan güçsüzlük, yıpranma, aşınma durumlarına denir. Aknar, Çiçek ve Karakaş (2018: 3) tükenmişliği, "duygusal ve bedensel talepler gerektiren durumlara aşırı miktarda ve uzun süre maruz kalmanın neden olduğu fiziksel, duygusal ve zihinsel tükenme durumu” olarak tanımlamıştır. Alanyazında tükenmişlik çalışmalarda en çok alıntılanan araştırmacılardan olan Maslach ve Jackson (1981: 99) tükenmişliğin çoğunlukla insanlara hizmet veren işlerde çalışan kişilerde duygusal tükenmişlik ve karamsarlık, ümitsizlik hisleri (sinizm) hali ile ortaya çıkan bir sendrom olduğunu ifade etmiştir. Maslach (1978, 1982) tükenmişliği iş ile ilgili düşük motivasyon, enerji kaybı, yıpranma gibi durumlarla baş gösteren ve çalışanın 
Süleyman Demirel Üniversitesi Vizyoner Dergisi, Yıl: 2020, Cilt: 11, Sayı: Ek, 50-64.

Süleyman Demirel University Visionary Journal, Year: 2020, Volume: 11, No: Supplement, 50-64.

artık hizmet sunduğu kişiye ve diğer kişilere karşı olumlu duygular besleyememesi halini alan bir sendrom olarak açıklamıştır. Maslach ve Jackson (1981) tükenmişliğin üç bileşeninden bahsetmiştir; bunlar sırasıyla şunlardır:

Duygusal Tükenmişlik (Emotional Exhaustion): Maslach'ın tükenmişlik araştırmalarında öne çıkan en önemli bileşen olan ve tükenmişliğe giden yolda ilk aşama olan duygusal tükenmişlik, çalışanların duygusal baş edebilme mekanizmalarının tükendiği anlamına gelmektedir (Sağlam Arı ve Çına Bal, 2008: 133). Bunun sonucunda birey hizmet sunduğu müşteriye karşı katılaşmış, sert tavırlar gösterir. Sürekli olarak insanların talepleri karşısında kendini zorlayan birey, yavaş yavaş duygusal kaynaklarını tüketir ve ruhen ve bedenen bitkin bir hal alır (Leiter ve Maslach, 1988: 298).

Duyarsızlaşma (Depersonalization): Kişiliğini kaybetme, benliğini yitirme anlamına gelen duyarsılaşma bireyin hizmet verdiği kiși ile olan ilişkisi boyutuyla ilgilidir (Barut ve Kalkan, 2002: 66). Duyarsızlaşma örgüte ve topluma karşı ilgisiz davranma, kayıtsız kalma, umursamama hali ile tarif edilir (Uslu ve Safa, 2020: 279). Bu olumsuz tavırlar hizmet verilen kişiye karşı soğuk davranma, ilgi göstermeme ve küçük düşürücü, bazen de aşağılayıcı bir tavır hal alabilmektedir (Maslach vd., 2001: 402-403).

Bireysel Başarı Duygusunun Azalması (Personal Accomplishment): Bu bileşende birey kendi kaynaklarını tükettiği için işinde başarılı olamayacağı algısına kapılır ve artık kendini başarısız addeder (Maslach vd., 2001: 402-403). Azalmış başarı duygusu ilk iki boyutun daha çok sonucu olarak ortaya çıkıp bireyin sorunlarla baş etmede kendisi faydasız ve başarısız olduğu düşüncelerine girmesidir. Sonuç olarak birey kendine olan öz saygısını ve inancını kaybedip, depresyona girmeye meyilli olur (Kıral, 2018: 927).

Tükenmişlik konusunda öncü isimlerden olan Maslach ve Leieter (2008: 38-39) tükenmişliği etkileyen etmenleri iş yükü, kontrol, ödüller, aidiyet, adalet ve değerler şeklinde kategorize etmiştir. Benzer şekilde, yürütülen araştırmalar tükenmişlik sendromu yaşayan çalışanların kişisel ve/veya örgütsel nedenlerden dolayı tükendiklerini ortaya koymuştur. Örneğin Kaplan ve Ulutaş (2016) emek yoğun olan otel işletmelerindeki gerçekleştirdikleri çalışmada duygusal emeğin çalışanların tükenmişliğine anlamlı bir etkiye sahip olduğunu saptamıştır. Yine turizm işletmelerinde yürütülen nicel bir araştırmaya göre çalışanların örgütsel adalet algıları ile tükenmişlik arasında negatif yönlü bir ilişki olduğu bulunmuştur (Pelit ve Bozdoğan, 2014). Alanyazındaki araştırmalar incelendiğinde tükenmişliğe etkisi olan göze çarpan örgütsel elementler arasında örgütte yeterli iletişim kanallarının olmaması, rollerin belirsizliği ve rol çatışması, örgütsel çatışma ve kötü liderlik anlayışı, iş güvensizliği, stres, taciz, psikolojik yıldırma ve yönetici desteğinin olmaması bulunmaktadır (Maslach ve Leieter, 1997; Um ve Harrison, 1998; Yürür ve Sarıkaya, 2011; Doğan, Demir ve Türkmen, 2016; Sart vd., 2018; Uzunbacak, Yıldız ve Uzun, 2019).

Çiçek ve Aknar'a göre (2019: 1237) “tükenmişlik bir anda ortaya çıkan bir psikolojik duygu durumu değildir. Çalışanların tükenmişlik sendromuna girmesi, işyerinde aşırı iş talepleri (duygusal ve bedensel) sonucu oluşan iş stresine uzun süreli ve yoğun bir şekilde maruz kalmaları durumunda ortaya çıkan duygu durumu" olarak ifade edilmiştir. Araştırmalardan görüldüğü üzere örgütteki olumsuz durum ve tavırlar bireylerin bedenen ve ruhen tükenmesine neden olmaktadır. İşyerinde dışlanma gibi bireyi yok sayan, kararlara katılması istenmeyen, ihmal edilen, göz ardı edilen bir süreçte, bireyler doğal olarak acı veren bu süreç içerisinde strese girip ruhsal olarak etkilenecektir. Önceki araştırmalar ve yukarıdaki açıklamalardan hareketle işyerinde dışlanmanın çalışanın tükenmişlik seviyesine bir etkiye sahip olacağı düşünülmektedir. Buna binaen çalışmanın hipotezinin şu şekilde kurulması uygun olacaktır:

\section{H1: İ̧ yerinde dışlanmanın tükenmişlik üzerinde pozitif yönlü etkisi vardır}

\section{3. İş Yerinde Dışlanma, Örgüt Temelli Öz Saygı ve Tükenmişlik Arasındaki İlişkisi}

İngilizce Self-Esteem olarak belirtilen, öz saygı Türk Dil Kurumuna göre insanın kendine duyduğu saygı, onur, haysiyet, izzetinefistir. 1960 lı yıllarda konuyu işleyen ilk düşünürlere göre öz saygı bireyin kendi yetkinlikleri hakkındaki öz değerlendirmesidir (Rosenberg, 1965). Öz saygı bireyin kendi özünü bir nesne olarak ele alıp kendi hakkında bir yargıya varma sürecidir. Başka bir deyişle bireyin özü hakkında olumlu olumsuz kanılarının sonucu kendinden hoşnut olup olmadığı bir durumdur (Doğru ve Peker, 2004: 316) Bu anlamda öz saygı bireylerin, başkalarının kendileri hakkında ne düşündüğünü yansıtan bireysel bir değerlendirmedir (Pierce ve Gardner, 2004: 592). Bireyin kendinden ne kadar memnun olduğunun derecesini gösteren öz saygı, aynı zamanda bireyin ne kadar değerli ve yeterli olduğunun ve geçmişte ihtiyaç duyduğu kendinden hoşnut olma durumunun düzeyini ifade eder (Korman, 1966: 479). Biraz daha açıklamak gerekirse öz sayg1, bireyin kendini kabullenmesi, beğenip, benimsenmesi olarak ifade edilebilir. Yapılan araştırmalar göre yüksek öz saygıya sahip bireyler kendileri 
Süleyman Demirel Üniversitesi Vizyoner Dergisi, Yıl: 2020, Cilt: 11, Sayı: Ek, 50-64.

Süleyman Demirel University Visionary Journal, Year: 2020, Volume: 11, No: Supplement, 50-64.

hakkında çok daha iyi hisse sahip oldukları ve özlerinden hoşnut oldukları ortaya konmuştur (Uçar ve Ötken, 2010: 90).

Öz saygı üzerine yürütülen araştırmalar incelenirken, öz saygının türlerinden bahsedilir. Bunlar sırasıyla şunlardır: Evrensel öz saygı (global self-esteem) bireyin genel değer değerlendirmesi; rol temelli öz saygı (role based selfesteem) çeşitli görevlerden doğan öz değerlendirmedir; görev temelli öz saygı (task based self-esteem) bir işi yerine getirirken bireyin öz yeterliliğine dayalı bir öz değerlendirme (Korman, 1966; Pierce, Gardner, Cummings ve Dunham, 1989; Pierce ve Gardner, 2004; Güney, Akalın ve İlsev, 2007). Bunlara ek olarak son yıllarda önemi artan bir öz saygı türü olarak ortaya çıkan örgüt temelli öz saygı (organization-based self-esteem) örgütsel davranış araştırmalarda irdelenmeye başlanmıştır. Pierce vd., (1989) tarafindan yapılan tanıma göre örgüt temelli öz sayg1, bireylerin örgüt içerisinde katıldıkları roller sayesinde kendilerinden hoşnut olma derecesini ifade eder. Bir başka deyişle örgüt temelli öz saygı, çalışanların kendilerini örgütsel ortamda önemli, anlamlı, etkili ve değerli gördükleri dereceyi yansitır (Schwalbe, 1988).

Self-efficacy yani öz yeterlilik ile karıştırılan örgüt temelli öz saygı, çalışanın kendisi ile ilgili algıyı tarif ederken, öz yeterlilik ise bu algının bir sonucu olarak bir işte yeterli olduğunun ortaya konmasıdır. Örgüt temelli öz sayg1 düzeyi yüksek olan bireyler öz yeterlilikleri yüksek olup kendilerinden memnundurlar, çünkü örgüt içerisinde kendilerinin değerli, önemli ve güvenilir oldukları algısına sahiptirler. Yapılan çalışmalara göre örgütsel bağlılığı yüksek olan çalışanların örgüt temelli öz saygısının da yüksek olduğu ortaya çıkmıştır (Lee ve Pecci, 2007). Bunun bir sebebi ise bu bireylerin psikolojik kendilerine güvendikleri ve kendilerinden tatmin oldukları ifade edilebilir. Alanyazında öz saygıyı etkileyen etmenler arasında öne çıkan önemli etmen iş çevresi olduğundan bahsedilir, örneğin iş yerinde bireye tanınan otonomi, örgütün sunduğu destek, yönetici veya iş arkadaşının sosyal desteği, duygusal stabilite, öz yeterlilik çalışanın örgüt temelli öz saygısını artırdığı görülmüştür (Viswesvaran, Sanchez ve Fisher, 1999; Chen, Goddard ve Casper, 2004; Pierce ve Gardner, 2004; Bowling, Eschleman, Wang, Kirkendall ve Alarcon, 2010). Öz saygının mahiyeti ve ilgili çalışmalar ışığında iş yerinde dışlanma gibi bireyin sosyal bir varlık olduğu ve kişisel ilişkiler geliştirmesi gerektiği gerçeğine tehdit olan bir unsur bireylerdeki örgüt temelli öz saygıyı azaltacağı beklenebilir. Dolayısıyla çalışmanın sıradaki hipotezin aşağıdaki gibi kurulması uygun görülmüştür:

\section{H2: İ̧ yerinde dışlanmanın örgüt temelli öz saygı üzerinde negatif yönlü etkisi vardır}

İş yerinde tükenmişlik yaşayan bireyler yıpranmış ve yorgun hissedip, fiziksel ve ruhsal olarak enerjisi kaybı yaşarlar. Tükenmişlik üzerine yapılan çalışmalara göre tükenen bireylerin iş yerinde verimlilikleri azalır, iş performansları düşer, işten ayrılma niyetleri artar, devamsızlıkları artar, yaşadıkları ıstırap bireysel yaşamlarında ise sağlık sorunları, evlilik ile ilgili problemleri yaşayabilmektedirler ve acılarını azaltmak için veya bu durumdan kaçmak için uyuşturucu ve alkol kullanabilmektedir (Tepper, 2000; Schaufeli ve Bakker, 2004; Maslach ve Leiter, 2008). Tükenen bireyler önce duygusal olarak tükenir daha sonra duyarsızlaşıp bir şeyleri başarabileceklerini düşünemeyip kendilerini yetersiz başarısız olarak görürler (Sağlam Arı ve Çına Bal, 2008: 133). Oysaki yukarıda anlatıldığ üzere birey kendini iş yerinde başarılı, değerli, önemli ve güvenilir hissetmesi sonucu kendini psikolojik olarak daha güçlü hisseder. Öz saygı örgütsel amaçları gerçekleştirmek için olumlu bir değişkendir. Öz saygisı yüksek bireyler daha pozitif tutum içinde oldukları için örgütün hedeflerini gerçekleştirmede önemli bir rol oynayabilirler çünkü kendilerinin örgütteki varlıkları örgütsel amaçları yerine getirmede etkili olduğunu düşünürler (Yüner, 2018: 778). Bu açıdan öz saygısı yüksek bireylerin öz saygısı düşük olanlara göre iş doyumu ve görev performansı daha yüksektir (Çakmak Otluoğlu, 2015; Hollenbeck ve Brief, 1987).

Tükenmişlik ile ilgili alanyazın incelendiğinde, tükenmişliği etkileyen çok sayıda faktör olduğu görülmektedir. Öne çıkanlar arasında, iş yükü, örgütsel adalet, iş tatminsizliği, örgütsel değer, liderlik tarzı, duygusal zeka, iş yerinde destek/sosyal destek, sorumluluk, başarıların takdir edilmesi/ödüllendirilmesi, yönetici ile etkileşim kalitesi, rol çatışması, öz yeterlilik ve kişilik özellikleri gibi faktörler bulunmaktadır (Budak ve Sürgevil, 2005; Aslan ve Özata, 2008; Kaşlı ve Aytemiz Seymen, 2010; Bolat, 2011; Karahan ve Uyanık Balat, 2011; Aslan ve Etyemez, 2015; Yıldız ve Çolak, 2018; Faiz, 2019). Araştırmalardan görüldüğü üzere tükenmişliği artırıp azaltan hem bireysel hem de örgütsel faktörler bulunmaktadır. Bolat (2011) gerçekleştirdiği araştırmaya göre öz yeterlilik algısı yüksek olan öğretmenlerin tükenmişlik düzeyleri düşük olduğu saptanmıştır. Benzer şekilde Karahan ve Uyanık Balat (2011) eğitimcilerle yaptıkları nicel araştırmaya göre öz yeterlilik algısı tükenmişliğin alt boyutları olan duygusal tükenme ve duyarsızlaşma ile negatif yönlü bir ilişki saptamıştır. Bu çalışma ise geçmiş araştırmalar 1şı̆̆ında, bireyin öz saygısının tükenmişlik üzerinde negatif yönlü bir etkisi olduğu savını ortaya koymaya çalışmaktadır. Buna göre araştırmanın üçüncü hipotezini aşağıdaki gibi kurmak uygun olacaktır: 
Süleyman Demirel Üniversitesi Vizyoner Dergisi, Yıl: 2020, Cilt: 11, Sayı: Ek, 50-64.

Süleyman Demirel University Visionary Journal, Year: 2020, Volume: 11, No: Supplement, 50-64.

\section{H3: Örgüt temelli öz saygı tükenmişlik üzerinde negatif yönlü etkisi vardır}

Geçmiş araştırmalar incelendiğinde, tükenmişlik yaşayan çalışanların bu hali yaşamasına neden olan olumsuz durumlar hem örgütsel hem de bireysel seviye gerçekleştiğini saptamıştır. Örneğin yönetici desteğinin hissedilmemesi, örgütsel adaletin algısının düşük olması, örgütsel çatışmalar, rol belirsizliği, duygusal emek, stres, gibi nedenlerden dolayı bireyler tükenmiş hissedebilirler (Maslach ve Leieter, 1997; Uğurluoğlu, Şantaş ve Demirgil, 2013; Kaplan ve Ulutaş, 2016; Sart vd., 2018). Benzer şekilde bu araştırmanın esas savlarından biri olan iş yerinde dışlanan bireylerin tükenmişliği artacağı düşünüldüğünde, bireyin öz saygısının burada bir aracılık role sahip olacağı düşünülebilir. Öz saygısı yüksek olan bireyler dışlanmaya maruz birakılsa bile kendinden hoşnut oldukları, kendileriyle barışık oldukları için tükenmişliğe kapılmayacakları beklenir; çünkü kendilerini kabul edip benimseyen bireyler daha çok olumlu hislere sahip olduğu ve iş yerleri için kendilerini daha faydalı gördüklerinden iş yerinde duygusal ve bedenen tükenmeyecekleri beklenmektedir (Barut ve Kalkan, 2002; Uçar ve Ötken, 2010; Uslu ve Safa, 2020). Buradan hareketle araştırmanın son hipotezini aşağıdaki gibi kurmak uygun olacaktır:

H4: Örgüt temelli öz saygl, iş yerinde dışlanma ve tükenmişlik arasındaki ilişkiye aracılık eder

\section{YÖNTEM}

$\mathrm{Bu}$ çalışmada işyerinde dışlanmanın tükenmişlik üzerindeki etkisi ve dışlanma, tükenmişlik ilişkisinde örgüt temelli öz saygının aracılık rolünün tespit edilmesi amaçlanmaktadır. Bu çoklu nedensel ilişkinin ortaya konulması için nicel araştırma yöntemlerinden anket tekniği kullanılmıştır. İnsan davranışlarını inceleyen bu araştırmanın etik kurul izni Muş Alparslan Üniversitesi Bilimsel Araştırma ve Yayın Etiği Kurulunun 24/06/2020 tarihli ve 10879717-050.01.04 sayılı kararına göre alınmıştır. Araştırmanın önerilen modeli Şekil 1'deki gibidir.

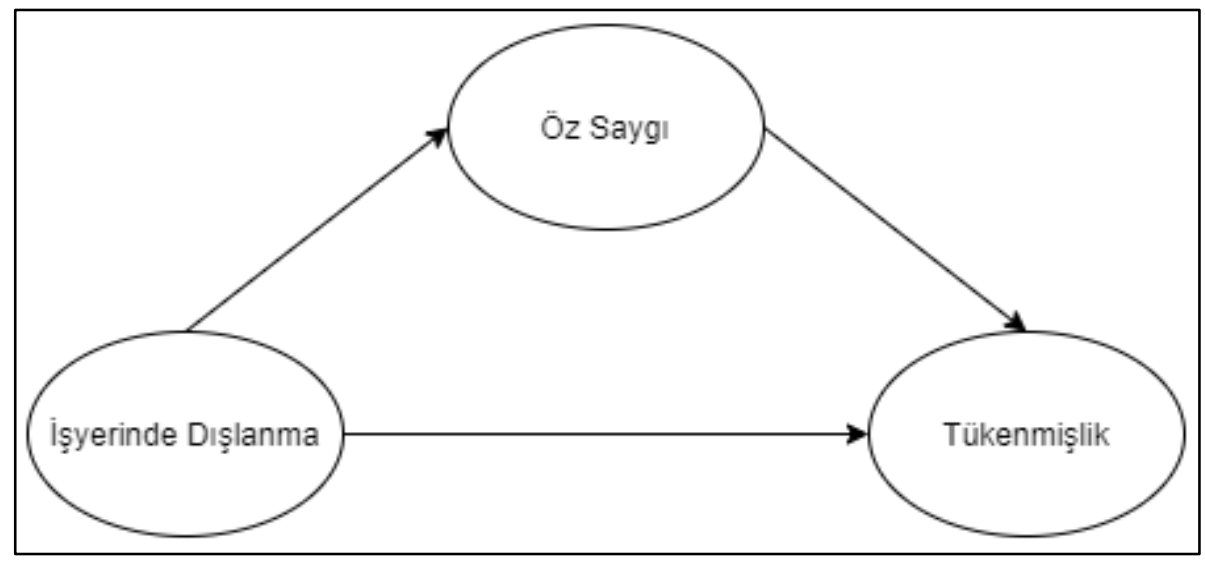

Şekil 1. Araştırma Modeli

\subsection{Veri ve Örnekleme}

Araştırmanın anakütlesini Şanlıurfa'da faaliyette bulunan hizmet sektörü çalışanları oluşturmaktadır. Anakütlenin tamamına ulaşmak mümkün olmadığından örnekleme yapılmıştır. Örnekleme yöntemi olarak kolayda örnekleme yöntemi tercih edilmiştir. TÜİK verilerine göre Şanlıurfa ilinin 2019 y1lı toplam nüfusu 2,073,614'tür. İl nüfusundan örneklem belirlemek için şu adımlar izlenmiştir: 1- toplam nüfustan çalışamayan nüfus çıkarılmıştır (0-15 ve 65 yaş üstü çıkarılmıştır), 2- çalışabilir nüfustan işgücüne katılım oranı bölgesel bazda ele alınarak oran tahminlemesi yapılmıştır (\%49,5), 3- Bulunan orandan bölgesel işsizlik oranı baz alınarak eksiltim yapılmıştır, 4Son olarak hizmet sektörünün bu oran içerisindeki payı (Erkeklerde \%45,1, Kadınlarda \%15,6) hesaplanarak anakütlenin 180,000 kişi civarında olduğu tespit edilmiştir. Cohen, Manion ve Morrison'a göre (2013) 180,000 anakütle için $\% 5$ hata payına ve $\% 95$ güven oranına göre örneklem büyüklügü̈ 384 olarak belirlenmiştir. Ayrıca 500,000 popülasyona kadar 384 sayısının temsil sorunu olmayacağı belirtilmiştir. Buradan hareketle araştırmaya katılan 401 kişinin anakütleyi temsil ettiği varsayılmıştır.

Google Formlar ile hazırlanan anket formu WhatsApp, Facebook, Twitter ve Instagram sosyal platformlar aracılığıyla hizmet sektörü çalışanlarına gönderilmiştir. Bu bağlamda öncelikle ulaşılabilecek çalışanların sosyal 
medya hesaplarından oluşan bir havuz oluşturulmuştur. Havuz oluşturulurken, geniş katılımın sağlanması ve konuyla ilgili olabileceği düşünülen bireylere ulaşabilme durumları göz önünde bulundurulmuştur. Oluşturulan havuzda kriterlere uygun 840 hizmet sektörü çalışanı yer almıştır. Böylece anket formu 840 kişiye ulaştırılmıştır ancak 410 kişi anketleri doldurarak geri dönmüş yapmıştır. Anketlerin geri dönüş oranı \%48,81'dir. 410 anketten 9'u aykırı değer oluşturduğu tespit edildiğinden değerlendirmeye alınmamıştır. Değerlendirmeye almaya uygun olan 401 anket anakütleyi temsil ettiğinden veri toplama sonlandırılmıştır.

\subsection{Veri Toplama}

İş yerinde dışlanma ölçeği: Araştırmanın bağımsız değişkeni olan iş yerinde dışlanmayı ölçmek amacıyla Ferris vd. (2008: 1366) tarafından geliştirilen, 13 maddeden oluşan dışlanma ölçeği kullanılmıştır.

Tükenmişlik ölçeği: Bağımlı değişken olan duygusal tükenmişliği ölçmek için Kristensen, Borritz, Villadsen ve Christensen (2005) tarafından geliştirilmiş olan tükenmişlik ölçeği kullanılmıştır. Kullanılan ölçek 7 ifade ve tek boyuttan oluşmaktadır.

Örgüt temelli öz saygı ölçeği: Araştırmanın aracı değişkeni olan özsaygıyı ölçmek için Steinfield, Ellison ve Lampe (2008) tarafından geliştirilen, Işık ve Çiçek (2020) tarafından Türkçeye uyarlanan öz saygı ölçeği kullanılmıştır. Ölçek 7 maddeden oluşmaktadır ve hem orijinal formunda hem de Türkçe uyarlamasında 3 . ve 5. maddeleri ters kodlanmıştır. Ölçek, sıralaması değiştirilmeden uygulanmıştır.

Tükenmişlik ve işyerinde dışlanma ölçeklerinin çalışmaya uygun Türkçe alternatiflerine rastlanılmadığından orijinal dillerindeki alternatifleri kullanılmıştır. Ölçekleri Türkçeleştirilirken Brislin (1980) tarafından önerilen "back translation” yöntemi uygulanmıştır. Kullanılan ölçek maddeleri hiç katılmıyorum en düşük ölçek aralığı ve tamamen katılıyorum en yüksek ölçek aralığı olacak şekilde 1'den 5'e kodlanmış 5'li Likert tipindedir.

\subsection{Veri Analizi}

Anket tekniği ile toplanan verilerin analizi için ise yapısal eşitlik modellemesi (YEM) benimsenmiştir. YEM'in tercih edilmesinin temel sebebi ise sosyal bilimler alanında teori destekli birkaç değişkenin ilişkisini, bir modelde ve birlikte analizini sağlamasıdır (Bayram, 2010: 41). Urbach ve Ahlemann (2010) YEM'in birinci nesil faktör analizi, çoklu regresyon analizi, doğrusal ayrımcılık analizi gibi analizlerin aksine, birden fazla bağımlı değişken ile bağımsız değişkenler arasındaki nedensel ilişkiyi aynı anda test edebilen ikinci nesil bir istatistiki yöntem olduğunu savunmuştur. Bu nedenle daha güçlü ve gerçeğe yakın sonuçlar alabilmek adına YEM yaklaşımı tercih edilmiştir. Verilerin analizinde SPSS 25 ve AMOS 22 programları kullanılmıştır.

\section{BULGULAR}

Katılımcıların demografik durumları incelendiğinde 238'inin kadın $(\% 59,4)$; 163 'ünün ise erkek $(\% 40,6)$ olduğu görülmüştür. Öğrenim durumlarına göre dağılımları: 138 ilköğretim mezunu $(\% 34,4), 181$ lise mezunu (\%45,1), 26 ön lisans mezunu $(\% 6,5), 56$ 'sı ise lisans ve üzeri $(\% 13,9)$ derece ile mezun olmuştur. Çalışanların yaş ortalaması 32,78, mevcut işyerlerinde çalışma süreleri ise ortalama 2,31 yıldır.

Araştırmada elde edilen veriler Anderson ve Gerbing'in (1988: 417-418) önerdiği iki aşamalı yapısal eşitlik modellemesi yaklaşımına göre test edilmiştir. Bu bağlamda hipotez testlerine geçilmeden önce ölçeklerin geçerlilik ve güvenilirlikleri test edilmiştir. Ölçeklerin geçerliliğini test etmek amacıyla öncelikle açımlayıcı faktör analizi (AFA) yapılmıştır. Ölçeklerin faktör analizine uygunluğunu tespit etmek için ise KMO ve Bartlett testi yapılmıştır. Ölçeklere ait KMO değerinin ,911 olduğu tespit edilmiştir. Bartlett değerinin ise $\chi 2=5824,324(120)$; $\mathrm{p}=, 000<0,05$ bulunmuştur. Buna göre ölçeklerin AFA için uygunluğu kanıtlanmıştır. Promax döndürme yöntemi ile yapılan AFA sonuçlarına göre ölçek maddelerinin aslına uygun dağılım gösterdiği belirlenmiştir. Daha sonra ölçeklere doğrulayıcı faktör analizi (DFA) yapılmıştır. DFA sonucunda elde edilen ölçeklere ait iyilik uyum indeksleri aşağıdaki Tablo 1'de verilmiştir. 
Süleyman Demirel Üniversitesi Vizyoner Dergisi, Yıl: 2020, Cilt: 11, Sayı: Ek, 50-64.

Süleyman Demirel University Visionary Journal, Year: 2020, Volume: 11, No: Supplement, 50-64.

Tablo 1. DFA Uyum İndeksleri

\begin{tabular}{|c|c|c|c|c|c|c|c|}
\hline & $\underset{<5}{\chi^{2} / \mathrm{df}}$ & $\begin{array}{l}\text { AGFI } \\
>0,85\end{array}$ & $\begin{array}{c}\text { GFI } \\
>\mathbf{0 , 8 0}\end{array}$ & $\begin{array}{c}\text { CFI } \\
>0,90\end{array}$ & $\begin{array}{c}\text { NFI } \\
>0,90\end{array}$ & $\begin{array}{c}\text { SRMR } \\
<0,08\end{array}$ & $\begin{array}{c}\text { RMSEA } \\
<\mathbf{0 , 0 8}\end{array}$ \\
\hline İş Yerinde Dışlanma & 1,983 & 0,96 & 0,97 & 0,98 & 0,99 & 0,036 & 0,038 \\
\hline Tükenmişlik & 2,286 & 0,97 & 0,98 & 0,97 & 0,96 & 0,028 & 0,041 \\
\hline ÖTÖS & 1,871 & 0,93 & 0,95 & 0,95 & 0,96 & 0,051 & 0,072 \\
\hline
\end{tabular}

Yapılan DFA sonucunda ölçeklerin mükemmel uyum değerlerine sahip olduğu görülmüştür (Kline, 2015). Fornell ve Larcker (1981) yapısal model test edilmeden önce ölçeklerin uyuşum ve ayırt edici geçerliliklerinin de test edilmesinin gerekliliğine değinmiştir. Buna göre iyilik uyum değerlerinin kabul edilebilir sınırlar içerisinde olması (Tablo 1), faktör yüklerinin 0,50'den yüksek olması, AVE değerlerinin 0,50'den yüksek olması ve CR değerlerinin 0,60'tan yüksek olması beklenmektedir. Ölçeklere ilişkin faktör yükleri, AVE ve CR değerleri ile Cronbach's Alpha değerleri Tablo 2'de verilmiştir. Tabloda 2'de yazılan “İD” İş Yerinde Dışlanmanın, “T” Tükenmişliğin ve "ÖS" ise Örgüt Temelli Öz Saygının kısaltmalarıdır.

Tablo 2. Uyuşum ve Ayırt Edici Geçerlik Analizi Sonuçları

\begin{tabular}{|c|c|c|c|c|}
\hline Maddeler & Faktör Yükü & $\alpha$ & CR & AVE \\
\hline & & 0,844 & 0,947 & $\mathbf{0 , 5 8 5}$ \\
\hline İD1 & 0,791 & & & \\
\hline İD2 & 0,674 & & & \\
\hline İD3 & 0,685 & & & \\
\hline İD4 & 0,632 & & & \\
\hline İD5 & 0,744 & & & \\
\hline İD6 & 0,831 & & & \\
\hline İD7 & 0,824 & & & \\
\hline İD8 & 0,859 & & & \\
\hline İD9 & 0,891 & & & \\
\hline İD10 & 0,879 & & & \\
\hline İD11 & 0,811 & & & \\
\hline İD12 & 0,585 & & & \\
\hline İD13 & 0,621 & & & \\
\hline
\end{tabular}


Süleyman Demirel Üniversitesi Vizyoner Dergisi, Yıl: 2020, Cilt: 11, Sayı: Ek, 50-64.

Süleyman Demirel University Visionary Journal, Year: 2020, Volume: 11, No: Supplement, 50-64.

\begin{tabular}{|c|c|c|c|c|}
\hline Maddeler & Faktör Yükü & $\alpha$ & CR & AVE \\
\hline \multicolumn{5}{|c|}{ Tükenmişlik } \\
\hline $\mathrm{T} 1$ & 0,853 & 0,891 & 0,898 & 0,564 \\
\hline $\mathrm{T} 2$ & 0,771 & & & \\
\hline $\mathrm{T} 3$ & 0,668 & & & \\
\hline $\mathrm{T} 4$ & 0,574 & & & \\
\hline $\mathrm{T} 5$ & 0,659 & & & \\
\hline T6 & 0,821 & & & \\
\hline $\mathrm{T} 7$ & 0,849 & & & \\
\hline
\end{tabular}

\begin{tabular}{|c|c|c|c|c|}
\hline \multicolumn{2}{|c|}{ Örgüt Temelli Öz Saygı } & \multirow{3}{*}{0,803} & \multirow{3}{*}{0,644} & \multirow[b]{2}{*}{0,915} \\
\hline ÖS1 & 0,421 & & & \\
\hline ÖS2 & 0,856 & & & \\
\hline ÖS3 (R) & 0,578 & & & \\
\hline ÖS4 & 0,811 & & & \\
\hline ÖS5 (R) & 0,544 & & & \\
\hline ÖS6 & 0,881 & & & \\
\hline ÖS7 & 0,821 & & & \\
\hline
\end{tabular}

Tablo 2'de görüldüğü üzere öz saygı ölçeğinin ilk maddesi dışında kalan tüm ifadelerin faktör yükü 0,50 eşiğinin üzerindedir. Bu nedenle öz saygı ölçeğinin ilk maddesi analizlerden çıkarılmıştır. Bunun dişında tüm Cronbach $\alpha$ değerleri ,80'den yukarı olduğundan ölçekler oldukça güvenilirdir. Ayrıca CR ve AVE değerleri de kabul edilen sınırın üzerindedir. Bu nedenle ölçeklerin geçerlilik ve güvenilirlik sorunu olmadığı tespit edilmiştir. Ölçeklerin aralarındaki korelasyon, ortalama ve standart sapma değerleri Tablo 3 'te verilmişstir.

Tablo 3. Tanımlayıcı İstatistikler

\begin{tabular}{lccccc}
\hline & Ort. & SS & $\mathbf{1}$ & $\mathbf{2}$ & $\mathbf{3}$ \\
\hline 1. İş Yerinde Dişlanma & 2,02 & 1,18 & - & & \\
2. Tükenmişlik & 2,93 &, 84 &, $541^{* * *}$ & - \\
3. Örgüt Temelli Öz Sayg1 & 3,25 &, 78 &,$- 278^{* * *}$ &,$- 228^{* * * *}$ & - \\
\hline
\end{tabular}


Süleyman Demirel Üniversitesi Vizyoner Dergisi, Yıl: 2020, Cilt: 11, Sayı: Ek, 50-64.

Süleyman Demirel University Visionary Journal, Year: 2020, Volume: 11, No: Supplement, 50-64.

\subsection{Yapısal Eşitlik Analizi}

İş yerinde dışlanmanın tükenmişlik üzerindeki etkisi ve bu ilişkide öz saygının rolünü ortaya koymak amacıyla yapısal eşitlik modellemesi yaklaşımı benimsenmiştir. AMOS v22 programı ile kurulan modelin iyi uyum değerlerine sahip olduğu görülmüştür. Kurulan modelin uyum iyiliği indeksleri $\chi 2 / \mathrm{df}=3.184$, RMSEA $=0.068$, $\mathrm{GFI}=0.955, \mathrm{AGFI}=0.963, \mathrm{TLI}=0.972, \mathrm{CFI}=0.974$ olarak ölçülmüştür. Modelin yol analizi sonuçları Tablo 4 'te verilmiştir.

Tablo 4. Doğrudan Etki Analizi Sonuçları

\begin{tabular}{lcccc}
\hline & Katsayı & S.E. & C.R. & P \\
\hline İşyerinde Dışlanma --> Tükenmişlik &, 346 &, 064 & 7,834 &, 000 \\
İşyerinde Dışlanma --> Örgüt Temelli Öz Saygı &,- 221 &, 059 & $-5,059$ &, 000 \\
Örgüt Temelli Öz Saygı --> Tükenmişlik &,- 285 &, 050 & $-6,453$ &, 000 \\
\hline
\end{tabular}

${ }^{1}$ Standardize edilmiş katsayılar verilmiştir.

Doğrudan etki analizi sonuçlarına göre işyerinde dışlanmanın tükenmişlik $(\beta=, 346 ; p<0,001)$ üzerinde pozitif ve anlamlı bir etkiye sahip olduğu görülmüştür. Ayrıca dışlanmanın özsaygı üzerinde $(\beta=-, 221 ; p<0,001)$ negatif ve anlamlı bir etkisi olduğu tespit edilmiştir. Bununla birlikte özsaygının ise tükenmişlik üzerinde $(\beta=-, 285 ; p<0,001)$ negatif yönlü ve anlamlı bir etkiye sahip olduğu belirlenmiştir. Bu durumda " $\mathrm{H} 1$ : İş yerinde dişlanmanın tükenmişlik üzerinde pozitif yönlü etkisi vardır", "H2: İş yerinde dışlanmanın örgüt temelli öz saygı üzerinde negatif yönlü etkisi vardır" ve "H3: Örgüt temelli öz saygı tükenmişlik üzerinde negatif yönlü etkisi vardır" hipotezleri desteklenmiştir.

Araştırmada aracı etki rolünü tespit etmek için Baron ve Kenny (1986) tarafindan önerilen standart prosedür Mallinckrodt, Abraham, Wei ve Russell (2006) tarafından önerilen bootstrapping yöntemi ile test edilmiştir. Bootstrap örneklem sayısı 5000 olarak hesaplanmıştır. Bu şekilde yapılan dolaylı etki analizinin sonuçları Tablo 5'teki gibidir.

Tablo 5. Dolaylı Etki Analizi Sonuçları

\begin{tabular}{lcccc}
\hline Hipotez & $\begin{array}{c}\text { Doğrudan Etki } \\
\boldsymbol{\beta}\end{array}$ & $\begin{array}{c}\text { Doğrudan Etki } \\
\boldsymbol{\beta}\end{array}$ & $\begin{array}{c}\text { Dolaylı Etki } \\
\boldsymbol{\beta}\end{array}$ & Aracılık Durumu \\
\hline H4a: İş_Dıs.-->ÖzSay.--> Tük. &, $346^{* * *}$ &, $189 *$ &, $121 * *$ & Kısmi Aracı \\
\hline
\end{tabular}

${ }^{1}$ Aracı Değişken Eklenmeden Önce; ${ }^{2}$ Aracı Değişken Eklendikten Sonra; $* * * p<0.001 ; * * \mathrm{p}<0.01 ; * \mathrm{p}<0.05$

Bootstrapping yöntemi ile yapılan dolaylı etki analizi sonucuna göre işyerinde dışlanma ile tükenmişlik ( $\beta=, 346$; $\mathrm{p}<0,001)$ arasındaki pozitif yönlü ilişki aracı değişken eklenmeden önce anlamlıdır. Aracı değişken olan öz saygı modele eklendiği takdirde ise ilişkinin gücü azalmaktadır $(\beta=, 189 ; \mathrm{p}<0,05)$. Ayrıca bootstrap yöntemi ile hesaplanan dolaylı etki parametresi $(\beta=, 121 ; \mathrm{p}<0,01)$ de anlamlıdır. Bu durumda öz saygının işyerindeki dışlanma ile tükenmişlik arasındaki ilişkiye kısmi aracılık ettiği sonucuna ulaşılmıştır ve "H4: Örgüt temelli öz sayg1 dışlanma ve tükenmişlik arasındaki ilişkiye aracılık eder” hipotezi kabul edilmiştir.

\section{TARTIŞMA}

Yapılan nicel araştırmanın sonucuna göre işyerindeki dışlanmanın tükenmişliği artırdığı sonucuna ulaşılmıştır. Çalışanların işyerindeki diğer arkadaşları tarafından dışlanması, sosyal olarak kendini ifade edememesi, iş ilişkilerinde gerginlikler de iş stresinin birer kaynağı olduğundan çalışanlara tükenmeye iten nedenlerdendir. Bu perspektiften ele alındığında iş arkadaşları tarafından bireyin dışlanmasının tükenmişlik ile sonuçlanması beklenen bir durumdur. Çalışmanın bulgusu alanyazındaki araştırmalarla benzerlik gösterdiği yönler olmuştur örneğin dışlanan bireylerin işten ayrılma niyet düzeyleri artarken (Pelit, 2018), diğer araştırmalarda ise dışlanan bireylerin 
Süleyman Demirel Üniversitesi Vizyoner Dergisi, Yıl: 2020, Cilt: 11, Sayı: Ek, 50-64.

Süleyman Demirel University Visionary Journal, Year: 2020, Volume: 11, No: Supplement, 50-64.

örgütsel sinizm seviyeleri artmaktadır (Yıldırım, 2016), yine benzer şekilde dışlanan çalışanların işe yabancılaşma düzeyleri artmaktadır (Abbaslı, 2018).

Araştırmanın bir diğer bulgusuna göre dışlanmanın öz saygıyı olumsuz etkilediği görülmüştür. Thomas ve Raj'ın (1985) çalışmasına göre öz saygının başlıca öncülleri sosyo-ekonomik statü, çevre, ilişkiler, karşlıklı güven ve kabul görmedir. Bu durumların seviyesi öz saygının seviyesi de belirlemektedir. Buradan hareketle işyerindeki dışlanmanın güven ortamını, ilişkileri, karşılıklı güven ve kabul görmeyi yıkacağından öz saygıyı düşürmesi oldukça beklenen bir durumdur. Araştırmanın bu bulgusu Doğan (2018) yürüttüğü çalışma ile benzerlikler taşımaktadır, örneğin bahsi geçen araştırmaya göre bireylerin algıladıkları sosyal destekler arttıkça öz güvenleri arttırmaktadır.

Öz saygının tükenmişlik üzerindeki ilişkisi incelendiğinde yüksek öz saygının tükenmişliği azalttığı görülmüştür. Yapılan çalışmalara göre öz saygısı yüksek olan bireyler kendilerini örgütler için değerli, önemli ve örgütsel amaçları gerçekleştirmede faydalı görmektedirler. Dolayısıyla öz saygısı yüksek olan çalışanların tükenme sürecine girmeyerek güçlü kalırlar. Yazındaki çalışmalar da araştırmanın bu bulgusu destekler nitelikte, örneğin Butler ve Constantine'in (2005) ve Gündüz'ün (2012) çalışmaları ile paralellik göstermektedir.

Araştırmada öz saygının dışlanma ile tükenmiş̧lik arasındaki ilişkiye aracılık ettiği görülmüştür. Çalışanların iş arkadaşların tarafından dışlanması sosyal ve psikolojik açıdan oldukça zedeleyici bir durumdur. Bu durumla baş edebilmek de bir o kadar güçtür. Bu durumun iş stresi, tükenme, işten ayrılma gibi sonuçları olabilmektedir. Her ne kadar bu durumla baş edebilmek oldukça güç olsa da bu çalışmada öz saygısı yüksek bireylerin dışlanmanın olumsuz sonuçlarıyla daha iyi baş edebildikleri görülmüştür.

\section{SONUÇ VE ÖNERILLER}

$\mathrm{Bu}$ çalışmada işyerindeki dışlanma, tükenmişlik ve örgüt temelli öz saygı arasındaki ilişkinin incelenmesi amaçlanmıştır. Literatürden hareketle kurulan hipotezlere göre tükenmişliğin bağımlı, işyerinde dışlanmanın bağımsız ve bu ilişkide öz saygının aracı değişken olduğu belirlenmiştir. Alanyazın incelendiğinde dışlanma, örgüt temelli öz saygı ve tükenmişliği bir araya getiren teorik bir model bulunmamaktadır. Bu üç değişkeni aynı modelde barından araştırma bulunmaması çalışmanın orijinalliğini ortaya koyan bir yönüdür. Çalışmanın bir başka katkısı da araştırmanın sonucuna göre iş yerinde dışlanan bireylerin tükenmişlik düzeyleri artmaktadır, örgüt temelli öz saygı ise bu modelde aracılık rolü üstlenmektedir. Bir başka deyişle, örgüt temelli öz saygı bu araştırmada dışlanan bireylerin tükenmesini önleyecek bir faktör olarak ortaya çıkmıştır. Yazındaki diğer çalışmalar, dışlanma ile tükenmişlik ilişkisini incelemesine rağmen örgüt temelli öz saygı gibi psikolojik bir etmenin rolünün hiç çalışılmaması çalışmanın özgünlüğünü ortaya koymaktadır. Öte yandan, bu araştırmanın sadece sonucuyla değil aynı zamanda çalışma hayatına yönelik önerileri açısından yazına katkıları bulunmaktadır.

Araştırma bulguları da göz önünde bulundurularak birtakım öneriler getirilmiştir. Bunlar:

- Örgütlerde, iş yerinde dışlanmanın minimize edilmesi için etik kurallar koyup işletilmesi gerekmekle birlikte kapsayıcı bir örgüt kültürü geliştirilmelidir.

- Örgütlerde, çalışanların tükenmişlik sendromuna yakalanmamaları için iş yüklerinin ve rollerinin belirlenmesi, örgütsel adalet algısının iyileştirilmesi gerekmektedir.

- Yöneticiler dışlayıcı olmayan bir anlayışla çalışanlara örgütsel destekleri hissettirmelidir ki olumsuz durumlarla karşılaşınca bu sorunların üstesinden gelebilsinler.

$\mathrm{Bu}$ araştırma iş yerinde dışlanıp tükenmeye itilen çalışanların öz saygıları vasıtasıyla tükenme düzeylerinin düş̧ebileceğini ortaya koyarak literatüre önemli bir katkıda bulunmaktadır. Fakat her araştırmanın olduğu gibi bu çalışmanın da birtakım sınırlılıkları vardır ve gelecekteki araştırmacılar buradan hareketle yeni çalışmalar gerçekleştirebilirler. Bu araştırma sadece bir kentte uygulandı gelecekteki araştırmalar daha geniş kitlelerle yapılıp daha genelleyici yargılara varılabilir. Bu araştırma sadece nicel yöntemler uygulanarak tamamlandı, gelecek çalışmalar çalışanlarla görüşmeler yaparak farklı bakış açıları ve detaylı hikayeler yakalayabilir. Yine bu çalışma üç değişken kullanılarak yapıldı, gelecekteki araştırmalar örgütsel şefkat, etik iklim, hizmetkar liderlik gibi değişkenlerin tükenmişlik, iş yerinde dışlanmaya olan etkilerini araştırabilir. 
Süleyman Demirel Üniversitesi Vizyoner Dergisi, Yıl: 2020, Cilt: 11, Sayı: Ek, 50-64.

Süleyman Demirel University Visionary Journal, Year: 2020, Volume: 11, No: Supplement, 50-64.

\section{KAYNAKÇA}

Abasl1, K. (2018). Örgütsel dışlanma, işe yabancılaşma ve örgütsel sinizm ilişsisine yönelik öğretmen görüşleri. Doktora Tezi, Hacettepe Üniversitesi Eğitim Bilimleri Enstitüsü, Ankara.

Aknar, A., Çiçek, B. ve Karakaş, Y. E. (2018). Çalışanların demografik özellikleri açısından tükenmişlik algıları: Belek’teki 5 yıldızlı oteller üzerine bir araştırma. International Journal of Management and Administration, 2(3), 1-16.

Anderson, J. C. ve Gerbing, D. W. (1988). Structural equation modeling in practice: A review and recommended two-step approach. Psychological Bulletin, 103(3), 411-423.

Aslan, Ş. ve Özata, M. (2008). Duygusal zekâ ve tükenmişlik arasındaki ilişkilerin araştırılması: Sağlık çalışanları örneği. Erciyes Üniversitesi İktisadi ve İdari Bilimler Fakültesi Dergisi, (30), 77-97.

Aslan, Z. ve Etyemez, S. (2015). İşgörenlerin tükenmişlik düzeylerinin işten ayrılma niyeti üzerine etkisi: Hatay'daki otel işletmelerinde bir araştırma. İşletme Araştırmaları Dergisi, 7(3), 482-507.

Baron, R. M. ve Kenny, D. A. (1986). The moderator-mediator variable distinction in social psychological research: Conceptual, strategic, and statistical considerations. Journal of Personality and Social Psychology, 51(6), 1173-1182.

Barut, Y. ve Kalkan, M. (2002). Ondokuz mayıs üniversitesi öğretim elemanlarının tükenmişlik düzeylerinin incelenmesi, Ondokuz Mayıs Üniversitesi Eğitim Fakültesi Dergisi, (14), 65-76.

Bayram, N. (2010). Yapısal eşitlik modellemesine giriş amos uygulamaları. Ezgi Kitabevi.

Bolat, O. İ. (2011). Öz yeterlilik ve tükenmişlik ilişkisi: lider-üye etkileşiminin aracıllk etkisi. Ege Akademik Bakış, 11(2), 255-266.

Bowling, N. A., Eschleman, K. J., Wang, Q., Kirkendall, C. ve Alarcon, G. (2010). A meta-analysis of the predictors and consequences of organization-based self-esteem. Journal of Occupational and Organizational Psychology, 83(3), 601-626.

Brislin, R. W. (1980). Translation and content analysis of oral and written materials. J. W. Berry ve H. C. Triandis (Ed.), Handbook of Cross-cultural Psychology içinde (389-444), Cambridge: Cambridge University Press.

Budak, G. ve Sürgevil, O. (2005). Tükenmişlik ve tükenmişliği etkileyen örgütsel faktörlerin analizine ilişkin akademik personel üzerinde bir uygulama. Dokuz Eylül Üniversitesi İktisadi ve İdari Bilimler Fakültesi Dergisi, 20(2), 95-108.

Butler, S. K. ve Constantine, M. G. (2005). Collective self-esteem and burnout in professional school counselors. Professional School Counseling, 9(1), 55-62.

Chen, G., Goddard, T. G. ve Casper, W. J. (2004). Examination of the relationships among general and work-specific self-evaluations, work-related control beliefs, and job attitudes. Applied Psychology, 53(3), 349-370.

Cohen, L., Manion, L. ve Morrison, K. (2013). Research methods in education. Routledge.

Çakmak Otluoğlu, K. Ö. (2015). Örgütsel nedenlerle yaşanan olumsuz şokların iş performansına etkisi: örgüt temelli özsaygının biçimlendirici değişken rolü. METU Studies in Development, 42(2), 221-246.

Çiçek, B. ve Aknar, A. (2019). Kişilik özelliklerinin tükenmişlik ve presenteizm davranışları üzerindeki etkisi. Third Sector Social Economic Review, 54(3), 1234-1258.

Doğan, A., Demir, R. ve Türkmen, E. (2016). Rol belirsizliğinin, rol çatışmasının ve sosyal desteğin tükenmişliğe etkisi: Devlet ve Vakıf üniversitelerinde çalışan akademik personelin tükenmişlik düzeylerinin karşılaştırılması. Atatürk Üniversitesi İktisadi ve İdari Bilimler Dergisi, 30(1), 37-67.

Doğan, İ. F. (2019). Algılanan sosyal destek ile yaşam tatmini ve özgüven ilişkisi: Göçmenler üzerinde bir araştırma. OPUS Uluslararası Toplum Araştırmaları Dergisi, (12), 586-606.

Doğru, N. ve Peker, R. (2004). Özsaygı geliştirme programının lise dokuzuncu sınıf öğrencilerinin özsaygı düzeylerine etkisi. Uludağ Üniversitesi Eğitim Fakültesi Dergisi, 17(2), 315-328. 
Süleyman Demirel Üniversitesi Vizyoner Dergisi, Yıl: 2020, Cilt: 11, Sayı: Ek, 50-64.

Süleyman Demirel University Visionary Journal, Year: 2020, Volume: 11, No: Supplement, 50-64.

Faiz, E. (2019). Aşırı iş yükü ve tükenmişlik sendromunun işten ayrılma niyeti üzerindeki etkisi: Satış personelleri üzerinde bir araştırma. Çalışma İlişkileri Dergisi, 10(1), 26-38.

Ferris, D. L., Brown, D. J., Berry, J. W. ve Lian, H. (2008). The development and validation of the workplace ostracism scale. Journal of Applied Psychology, 93(6), 1348-1366.

Fornell, C. ve Larcker, D. F. (1981). Evaluating structural equation models with unobservable variables and measurement error. Journal of Marketing Research, 18(1), 39-50.

Fox, S. ve Stallworth, L. E. (2005). Racial/ethnic bullying: exploring links between bullying and racism in the US workplace. Journal of Vocational Behavior, 66(3), 438-456.

Freudenberger, H. J. (1974). Staff burn-out. Journal of Social Issues, 30(1), 159-165.

Gündüz, B. (2012). Self-efficacy and burnout in professional school counselors. Educational Sciences: Theory and Practice, 12(3), 1761-1767.

Güney, S., Akalın, Ç. ve İlsev, A. (2007). Duygusal örgütsel bağlılık gelişiminde algılanan örgütsel destek ve örgüt temelli öz-saygı. Hacettepe Üniversitesi İktisadi ve İdari Bilimler Fakültesi Dergisi, 25(2), 189-211.

Hitlan, R. T., Cliffton, R. J. ve DeSoto, M. C. (2006). Perceived exclusion in the workplace: The moderating effects of gender on work-related attitudes and psychological health. North American Journal of Psychology, 8(2), 217-236.

Hollenbeck, J. R. ve Brief, A. P. (1987). The effects of individual differences and goal origin on goal setting and performance. Organizational Behavior and Human Decision Processes, 40(3), 392-414.

Hughes, L. W. ve Palmer, D. K. (2007). An investigation of the effects of psychological contract and organizationbased self-esteem on organizational commitment in a sample of permanent and contingent workers. Journal of Leadership and Organizational Studies, 14(2), 143-156.

Işık, M. ve Çiçek, B. (2020). Planlı davranış teorisi perspektifinden girişimcilik niyeti üzerinde sosyal sermaye, öz yeterlilik ve öz saygının rolü. Turkish Studies - Economics, Finance, Politics, 15(1), 185-206.

Kaplan, M. ve Ulutaş, Ö. (2016). Duygusal emeğin tükenmişlik üzerindeki etkisi: Otel işletmelerinde bir araştırma. Selçuk Üniversitesi Sosyal Bilimler Enstitüsü Dergisi, (35), 165-174.

Karabey, C. N. (2014). İşyerinde dişlanma. Ankara: İmaj.

Karahan, Ş. ve Uyanık Balat, G. (2011). Özel eğitim okullarında çalışan eğitimcilerin öz-yeterlik algılarının ve tükenmişlik düzeylerinin incelenmesi. Pamukkale Üniversitesi Eğitim Fakültesi Dergisi, 29(29), 1-14.

Kaşlı, M. ve Aytemiz Seymen, O. (2010). Kişilik özellikleri, lider-üye etkileşimi ve tükenmişlik ilişkisi. Dumlupinar Üniversitesi Sosyal Bilimler Dergisi, (27).

Kıral, B. (2018). Anadolu lisesi öğretmenlerinin tükenmişlik düzeylerinin çeşitli değişkenlerle ilişkisi. Anemon Muş Alparslan Üniversitesi Sosyal Bilimler Dergisi, 6(6), 925-934.

Kline, R. B. (2015). Principles and practice of structural equation modeling. New York: Guilford Publications.

Korman, A. K. (1966). Self-esteem variable in vocational choice. Journal of Applied Psychology, 50(6), 479-486.

Kristensen, T. S., Borritz, M., Villadsen, E. ve Christensen, K. B. (2005). The Copenhagen burnout inventory: A new tool for the assessment of burnout. Work \& Stress, 19(3), 192-207.

Lee, J. ve Peccei, R. (2007). Perceived organizational support and affective commitment: the mediating role of organization-based self-esteem in the context of job insecurity. Journal of Organizational Behavior, 28(6), 661-685.

Leiter, M. P. ve Maslach, C. (1988). The impact of interpersonal environment on burnout and organizational commitment. Journal of Organizational Behavior, 9(4), 297-308.

Leung, A. S., Wu, L. Z., Chen, Y. Y. ve Young, M. N. (2011). The impact of workplace ostracism in service organizations. International Journal of Hospitality Management, 30(4), 836-844. 
Süleyman Demirel Üniversitesi Vizyoner Dergisi, Yıl: 2020, Cilt: 11, Sayı: Ek, 50-64.

Süleyman Demirel University Visionary Journal, Year: 2020, Volume: 11, No: Supplement, 50-64.

Mallinckrodt, B., Abraham, W. T., Wei, M. ve Russell, D. W. (2006). Advances in testing the statistical significance of mediation effects. Journal of Counseling Psychology, 53(3), 372-378.

Maslach, C. (1978). The client role in staff burn-out. Journal of Social Issues, 34(4), 111-124.

Maslach, C. (1982). Burnout: The cost of caring. Prentice-Hall, Englewood Cliffs, NJ.

Maslach, C. ve Leiter, M. P. (2008). The truth about burnout: how organizations cause personal stress and what to do about it. John Wiley ve Sons.

Maslach, C., Schaufeli, W. B. ve Leiter, M. P. (2001). Job burnout. Annual Review of Psychology, 52(1), $397-422$.

Maslach, C. ve Jackson, S. E. (1981). The measurement of experienced burnout. Journal of Organizational Behavior, 2(2), 99-113.

Maslow, A. H. (1943). A theory of human motivation. Psychological Review, 50(4), 370-396.

Pelit, E. ve Bozdoğan, İ. (2014). Çalışanların örgütsel adalet algılamalarının tükenmişlik düzeyleri üzerindeki etkisi: Kemer'deki beş yıldızlı otel işletmelerinde bir uygulama. İşletme Araştırmaları Dergisi, 6(2), 37-66.

Pelit, O. (2018). Örgütsel dışlanmanın işten ayrılma niyetine etkisi: Afyonkarahisar'daki beş yıldızlı otel işletmelerinde bir araştırma. Yüksek Lisans Tezi, Afyon Kocatepe Üniversitesi Sosyal Bilimler Enstitüsü, Afyonkarahisar.

Pierce, J. L. ve Gardner, D. G. (2004). Self-esteem within the work and organizational context: A review of the organization-based self-esteem literature. Journal of Management, 30(5), 591-622.

Pierce, J. L., Gardner, D. G., Cummings, L. L. ve Dunham, R. B. (1989). Organization-based self-esteem: construct definition, measurement, and validation. Academy of Management Journal, 32(3), 622-648.

Robinson, S. L., O’Reilly, J. ve Wang, W. (2013). Invisible at work: An integrated model of workplace ostracism. Journal of Management, 39(1), 203-231.

Rosenberg, M. (1965). Society and the adolescent self-image. Princeton: NJ. Princeton University Press.

Sağlam Arı, G. ve Çına Bal, E. (2008). Tükenmişlik kavramı: bireyler ve örgütler açısından önemi. Yönetim ve Ekonomi, 15(1),131-148.

Sapancalı, F. (2005). Sosyal dışlanma. İzmir: Dokuz Eylül Yayınları.

Sart, G, Sezgin, F. H. ve Demir, N. (2018). Mobbingin mesleki tükenmişlik algısı üzerine etkileri: Kadın akademisyenler örneği. Beykoz Akademi Dergisi, 6(1), 118-135.

Schaufeli, W. B. ve Bakker, A. B. (2004). Job demands, job resources, and their relationship with burnout and engagement: A multi-sample study. Journal of Organizational Behavior, 25(3), 293-315.

Schwalbe, M. L. (1988). Sources of self-esteem in work: What's important for whom?. Work and Occupations, 15(1), 24-35.

Soybalı, H. H. ve Pelit, O. (2018). Örgütsel dışlanmanın işten ayrılma niyetine etkisi: Afyonkarahisar'daki beş yıldızlı otel işletmelerinde bir araştırma. Afyon Kocatepe Üniversitesi Sosyal Bilimler Dergisi, 20(3), 225-249.

Steinfield, C., Ellison, N. B. ve Lampe, C. (2008). Social capital, self-esteem, and use of online social network sites: A longitudinal analysis. Journal of Applied Developmental Psychology, 29(6), 434-445.

Tepper, B. J. (2000). Consequences of abusive supervision. Academy of Management Journal, 43(2), 178-190.

Thomas, I. ve Raj, H. S. (1985). A factor analytical study on the antecedents of self-esteem. Psychological Studies, 30(2), 97-101.

Topateş, H. (2009). Araçsallaştırılmış bir kavram olarak sosyal dışlanma. Çalışma ve Toplum Dergisi, (4), 115-130.

Uçar, D. ve Ötken, A. B. (2010). Perceived organizational support and organizational commitment: The mediating role of organization based self-esteem. Dokuz Eylül Üniversitesi İktisadi ve İdari Bilimler Fakültesi Dergisi, 25(2), 85-105. 
Uğurluoğlu, Ö., Şantaş, F. ve Demirgil, B. (2013). Lider-üye etkileşimi ve tükenmişlik ilişkisi: Hastanelerde bir uygulama. Hacettepe Sağllk İdaresi Dergisi, 16(1), 1-21.

Um, M. Y. ve Harrison, D. F. (1998). Role stressors, burnout, mediators, and job satisfaction: A stress-strainoutcome model and an empirical test. Social Work Research, 22(2), 100-115.

Urbach, N. ve Ahlemann, F. (2010). Structural equation modeling in information systems research using partial least squares. Journal of Information Technology Theory and Application, 11(2), 5-40.

Uslu, M. A. ve Safa, A. (2020). Öğretmenlerin tükenmişlik düzeylerinin maslach tükenmişlik envanteri ile incelenmesi: Batman ilinde yapılan bir araştırma. Anemon Muş Alparslan Üniversitesi Sosyal Bilimler Dergisi, 8(1), 277-284.

Uzunbacak, H. H., Yıldız, A. ve Uzun, S. (2019). Toksik liderliğin çalışanların tükenmişlik düzeylerine etkisi. Anemon Muş Alparslan Üniversitesi Sosyal Bilimler Dergisi, 7(1), 211-219.

Viswesvaran, C., Sanchez, J. I. ve Fisher, J. (1999). The role of social support in the process of work stress: A meta-analysis. Journal of Vocational Behavior, 54(2), 314-334.

Vui Yee, K. ve Yen Hwa, T. (2019). When does ostracism lead to turnover intention? The moderated mediation model of job stress and job autonomy. IIMB Management Review.

Walker, A. ve Walker, C. (1997). Britain divided: the growth of social exclusion in the 1980s and 1990s. London. Child Poverty Action Group.

Williams, K. D. (1997). Social ostracism. R. M. Kowalski (Ed.), Aversive interpersonal behaviors. The Springer Series in Social/Clinical Psychology içinde (133-170), Boston, MA: Springer.

Williams, K. D. (2007). Ostracism. Annual Review of Psychology. (58), 425- 452.

Wu, C. H., Liu, J., Kwan, H. K. ve Lee, C. (2016). Why and when workplace ostracism inhibits organizational citizenship behaviors: An organizational identification perspective. Journal of Applied Psychology, 101(3), 362-378.

Yıldırım, E. ve Akın, M. (2018). Örgütlerde dışlanma, sinizm ve pozitif-negatif duygusallık arasındaki ilişkiler: Pozitif ve negatif duygusallığın aracılık rolü, Uluslararası Yönetim İktisat ve Isşletme Dergisi, 14(2), 427449.

Yıldız, S. ve Çolak, U. (2018) Liderlik davranış tarzlarının örgütsel tükenmişlik ve işten ayrılma eğilimlerine etkileri: Seyahat acentaları üzerine bir araştırma. MANAS Sosyal Araştırmalar Dergisi, 7(4), 607-632.

Yin, K. ve Liu, Y. R. (2013). Workplace ostracism and turnover intention: The roles of organizational identification and career resilience. Soft Science, 27(4), 121-124.

Yüner, B. (2018). Örgüt temelli öz saygı ve örgütsel duygusal bağl1lı̆ga ilişkin öğretmen görüşleri. Özel Eğitim Dergisi, 19(4), 777-799.

Yürür, S. ve Sarıkaya, M. (2011). Sosyal çalışmacıların sosyal destek algılarının tükenmişliğe etkisi. Ege Akademik Bakış, 11(4), 537-552.

Yürür, Ş. (2011). Öğrenilmiş güçlülük, kıdem ve medeni durumun duygusal tükenmedeki rolü: Kaynakların korunması teorisi kapsamında bir analiz. Atatürk Üniversitesi İktisadi ve İdari Bilimler Dergisi, 25(1), 107-126.

Zhao, H., Peng, Z. ve Sheard, G. (2013). Workplace ostracism and hospitality employees' counterproductive work behaviors: The joint moderating effects of proactive personality and political skill. International Journal of Hospitality Management, (33), 219-227. 